\title{
Article \\ Performance Evaluation of Enzyme Breaker for Fracturing Applications under Simulated Reservoir Conditions
}

\author{
Yuling Meng ${ }^{1}$, Fei Zhao ${ }^{1}$, Xianwei Jin ${ }^{1} \mathbb{D}$, Yun Feng ${ }^{2}$, Gangzheng Sun ${ }^{2}$, Junzhang Lin ${ }^{2}$, \\ Baolei Jia 1,3 and Piwu Li ${ }^{1,3, *}$
}

1 Key Laboratory of Shandong Microbial Engineering, Shandong Academy of Sciences, Qilu University of Technology, Jinan 250353, China; 1043118305@stu.qlu.edu.cn (Y.M.); 1043119623@stu.qlu.edu.cn (F.Z.); crazyelton@163.com (X.J.); baoleijia@cau.ac.kr (B.J.)

2 Research Institute of Petroleum Engineering and Technology, Shengli Oilfield Company, Sinopec, Dongying 257029, China; fengyun866.slyt@sinopec.com (Y.F.); sungangzheng.slyt@sinopec.com (G.S.); linjunzhang.slyt@sinopec.com (J.L.)

3 State Key Laboratory of Biobased Material and Green Papermaking (LBMP), Shandong Academy of Sciences, Qilu University of Technology, Jinan 250353, China

* Correspondence: piwuli@qlu.edu.cn; Tel.: +86-156-1571-5965

Citation: Meng, Y.; Zhao, F.; Jin, X.; Feng, Y.; Sun, G.; Lin, J.; Jia, B.; Li, P. Performance Evaluation of Enzyme Breaker for Fracturing Applications under Simulated Reservoir Conditions. Molecules 2021, 26, 3133. https://doi.org/10.3390/

molecules26113133

Academic Editor: Alicia Prieto

Received: 3 April 2021

Accepted: 20 May 2021

Published: 24 May 2021

Publisher's Note: MDPI stays neutral with regard to jurisdictional claims in published maps and institutional affiliations.

Copyright: (c) 2021 by the authors. Licensee MDPI, Basel, Switzerland. This article is an open access article distributed under the terms and conditions of the Creative Commons Attribution (CC BY) license (https:// creativecommons.org/licenses/by/ $4.0 /)$.

\begin{abstract}
Fracturing fluids are being increasingly used for viscosity development and proppant transport during hydraulic fracturing operations. Furthermore, the breaker is an important additive in fracturing fluid to extensively degrade the polymer mass after fracturing operations, thereby maximizing fracture conductivity and minimizing residual damaging materials. In this study, the efficacy of different enzyme breakers was examined in alkaline and medium-temperature reservoirs. The parameters considered were the effect of the breaker on shear resistance performance and sand-suspending performance of the fracturing fluid, its damage to the reservoir after gel breaking, and its gel-breaking efficiency. The experimental results verified that mannanase II is an enzyme breaker with excellent gel-breaking performance at medium temperatures and alkaline conditions. In addition, mannanase II did not adversely affect the shear resistance performance and sandsuspending performance of the fracturing fluid during hydraulic fracturing. For the same gelbreaking result, the concentration of mannanase II used was only one fifth of other enzyme breakers (e.g., mannanase I, galactosidase, and amylase). Moreover, the amount of residue and the particle size of the residues generated were also significantly lower than those of the ammonium persulfate breaker. Finally, we also examined the viscosity-reducing capability of mannanase II under a wide range of temperatures $\left(104-158^{\circ} \mathrm{F}\right)$ and $\mathrm{pH}$ values (7-8.5) to recommend its best-use concentrations under different fracturing conditions. The mannanase has potential for applications in low-permeability oilfield development and to maximize long-term productivity from unconventional oilwells.
\end{abstract}

Keywords: hydraulic fracturing; gel breaking; enzyme breaker; mannanase

\section{Introduction}

Owing to global reductions in the number of recoverable conventional oil reservoirs, by 2035, oil resources recovered from low-permeability reservoirs will account for approximately half of all newly developed oil production projects. Hydraulic fracturing has proved to be one of the most economically competitive technologies that can be applied to improve productivity and maximize recovery in low-permeability reservoirs [1] The principle underlying hydraulic fracturing involves the use of high-viscosity fluids to generate high-conductivity fractures and transport proppants into the fractures. Subsequently, high-viscosity fluids should be rapidly converted into a low-viscosity fluid, which should then flow back to the reservoir surface [2]. Therefore, in this study, an efficient and useful enzyme breaker was selected and applied to complete the viscosity reduction process after the fracturing operation to ensure easy flow-back and efficient clean-up of the propped fractures. 
In general, the additives to hydraulic fracturing fluids are composed of a thickening agent, a crosslinker, breakers, a proppant, a $\mathrm{pH}$ adjustment system, a fungicide, and a clay stabilizer. The most important additives that influence hydraulic fracturing fluids are the thickening agent and breaker. In particular, guar-based polymers are currently the most reliable thickening agents for hydraulic fracturing [3]. Considering their satisfactory viscosity and rheology, they can deliver higher proppant concentrations than their lowerviscosity analogues. In addition, guar gum is also a relatively low-cost natural material with a high affinity for water [4]. Guar-based polymers are high-molecular-weight biopolymers, in which the main chain consists of mannose, with galactose as the side chains, such that the ratio of mannose to galactose varies from 1.6:1 to 1.8:1 [5]. Previous studies have reported that the polymer viscosity, which reflects its stability, exhibits a positive correlation with molecular weight. In guar-based polymers, the $\beta-1,4$-glycosidic bond of the mannose main chains is crucial to maintain polymer stability [6,7]. In addition, the $\alpha-1,6$-glycosidic bonds in the side chain can also experience degradation, thereby reducing the viscosity of guar-based polymers, which is useful for viscosity reduction after fracturing [2]. This feature of guar-based polymers can be used to select suitable breakers that ensure the elimination or minimization of residual gel damage while optimizing well stimulation.

Ideally, to reduce the gel residue, an efficient and adaptive breaker should cleave polymers into low-molecular-weight fragments. Breakers for crosslinked gels are usually categorized as enzymes and oxidizers [8]. Oxidative breakers (e.g., peroxydisulfates, bromates, and peroxides) are most commonly used for the clean-up treatment of residues [9]. However, when they are used in the process of polymer degradation, the process is random and uncontrollable. This is usually because, after fracture formation, oxidizers degrade the guar fluid and reduce the viscosity of the fracturing fluid by producing free radicals owing to thermal decomposition [10-12]. Fuller [2,13] estimated that the efficacy of the oxidative breaker is strongly dependent on its activity and concentration. In a lower temperature reservoir, lower oxidant reactivities result in limited thermal decomposition, which may lead to fracturing failure; therefore, the oxidant is difficult to use for the purpose of breaking the gel during the low-temperature hydraulic fracturing process [11]. Therefore, a higher concentration breaker is required in medium-low temperature reservoirs, relative to high-temperature reservoirs. Sarwar et al. [14-16] examined the amount of residue remaining after the addition of oxidative breakers to the fracturing fluid over a wide range of temperatures $\left(68-212^{\circ} \mathrm{F}\right)$. In particular, the filter cake formed as a result of the generation of a substantial amount of residue can cause formation fracture blockage and a reduced oil yield. In addition, these oxidizers are often strongly incompatible with many common fracturing additives, such as organic materials, and require special consideration during their deployment and storage [17]. Although they are relatively common and readily available, their low reactivity and uneven residue removal ability do not favor their application in medium-temperature reservoirs.

To overcome these drawbacks, enzyme breakers, which offer the possibility of efficient and controllable degradation while achieving complete gel breakage, have been introduced [18]. In general, the enzymes used are proteins, consisting of amino acid chains, which can degrade polysaccharide polymers via the hydrolysis of the connective bonds; each enzyme degrades a certain chemical bond in the polymer backbone. As biocatalysts for polymer-breaking reactions, enzyme breakers offer significant advantages over traditional oxidative breakers [13]. First, enzyme breakers only hydrolyze the polymers in the hydraulic fracturing fluids, thereby avoiding the occurrence of undesirable reactions that affect the wellbore, formation, or fracturing equipment [17]. Second, they can effectively "break" guar polymers into monosaccharides or oligosaccharides, leading to a significant reduction in the amount of residue generated [19]. Third, the gel-breaking reaction performed using enzyme breakers is mild and controllable, guaranteeing a sufficient supporting force at the initial stage of fracturing construction to enable crack formation and deliver the proppant $[20,21]$. However, the stability (spatial structure) of enzyme breakers is strongly affected by environmental factors, such as temperature and $\mathrm{pH}$ [22]. In general, as the 
temperature and $\mathrm{pH}$ increase, there is an increase in the tendency of the three-dimensional conformation of the enzyme to change from the folded active state to the unfolded inactive state [23]. Therefore, a new breaker is required to break the traditional $\mathrm{pH}$ and temperature limits, which can operate under alkaline and medium-temperature reservoir conditions, as well as playing an important role in the field of hydraulic fracturing.

Considering the specificity of enzymes in targeting polymer links and their stabilities with respect to different environmental conditions, previous studies have investigated several high-performance hydrolase breakers that can specifically degrade the glycosidic bonds of guar-based polymers, such as mannanase, cellulase, galactosidase, and amylase [24-28]. However, the existing literature does not include reports on enzyme breakers with higher gel-breaking efficiency in medium-temperature and alkaline reservoirs. Therefore, our research was conducted under simulated medium and low temperatures and alkaline reservoir conditions, to identify the enzyme breaker with the optimum gel-breaking effect under this condition.

Mannanase is a type of enzyme that specifically decomposes $\beta$-1,4-glycosidic bonds. Thus far, it has been widely applied in the feed, medicine, and food industries. Although mannanase had not been widely applied in hydraulic fracturing, some progress has been made since its introduction. When compared with other breakers, mannanase can degrade polymers more thoroughly and generates reduced gel residue. Moreover, some authors reported that a certain type of mannanase exhibits higher activity for high temperatures and a wide $\mathrm{pH}$ range [29-31]. These properties make it a superior enzyme breaker that can be an excellent alternative to the use of harsh treatments in alkaline and mediumtemperature formations. However, the effectiveness of this enzyme has not been verified in the site experiments of fracturing operations, and the best-use concentration of the enzyme breaker under different conditions has not been determined. The best amount of breaker can not only achieve the goal of low damage and low cost for the fracturing fluid system, but also achieve the effect of increasing the flowback rate and increasing production of low-permeability reservoirs. Therefore, in this study, the indoor evaluation of the gel-breaking effect and applicability of mannanase and other enzyme breakers was carried out by simulating the reservoir conditions $\left(158^{\circ} \mathrm{F}, \mathrm{pH}=8.5\right)$ of the Xinjiang Shengli Oilfield [32-34]. In addition, the best-use concentration of the optimal enzyme breaker has been determined under other broader conditions.

\section{Materials and Methods}

\subsection{Materials}

This study was conducted in 2019 at the Laboratory of Biobased Material \& Green Papermaking, Qilu University of Technology, China. The ammonium persulfate breaker (APS), thickening agent, clay stabilizer, fungicide, and other chemical additives were provided by the SinoPEC Shengli Oil Field Ltd. Co. (Dongying, China). A series of enzyme breakers was provided by the Shandong Longda Bio-Products Co., Ltd. (Linyi, China). The crosslinker and $\mathrm{pH}$ adjustment system were purchased from the Damao Chemical Reagent Factory (Tianjin, China). The basic components of the fracturing fluid used in this study are listed below.

Thickening agent: A guar gum blend was used as the thickening agent in all of the experiments in this study. The blend consisted of a high viscosity, chemically modified polysaccharide that disperses readily and subsequently self-hydrates to yield a viscous solution.

Crosslinker $(0.35 \% w / w)$ : Sodium borate was used as a source of borate ions to crosslink the guar gum polymer. The borate ions generated 1:10 complexes with the guar chains.

$\mathrm{pH}$ adjustment system: Sodium hydroxide $(0.1 \mathrm{M})$ and hydrochloric acid $(0.1 \mathrm{M})$ were used as the $\mathrm{pH}$ adjust system, which was used to maintain optimal $\mathrm{pH}$ conditions for the reaction between the thickening agent and crosslinker.

Additives: The clay stabilizer $(0.2 \% w / w)$, fungicide $(0.2 \% w / w)$, and other chemical additives were added as per their actual use in hydraulic fracturing treatments in the field. 
Breakers: Mannanase I (CAS: 37288-54-3), mannanase II (CAS: 37288-54-3), amylase (CAS: 9000-92-4), cellulase (CAS: 9012-54-8), pectinase (CAS: 9032-75-1), xylanase (CAS: 9025-57-4), galactosidase (CAS: 9031-11-2), glucanase (CAS: 9025-70-1), and ammonium peroxydisulfate (CAS: 7727-54-0) were the breakers used in the experiments.

\subsection{Methods}

2.2.1. Effect of Breaker on Shear Resistance Performance and Sand-Suspending Performance of the Fracturing Fluid

In general, guar concentrations in the range of $0.12-0.96 \% w / w$ are used for hydraulic fracturing operations [35]. However, a polymer loading of $0.4 \% w / w$ is more suitable for common oilfield fracturing conditions. Therefore, in our experiments, a guar gum gel concentration of $0.4 \% w / w$ was used. First, a sufficient amount of the guar gum was used to prepare a $500-\mathrm{mL} 0.4 \% w / w$ solution. The solution was stirred at $600 \mathrm{rpm}$ for $5 \mathrm{~min}$, additionally, the polymer was allowed to hydrate for $4 \mathrm{~h}$ at $200 \mathrm{rpm}$. Second, 1-mL concentrations of $0.2 \% w / w$ clay stabilizer, fungicide, and other fracture additives were separately added to $50-\mathrm{mL}$ of $0.35 \% w / w$ borax solution. Thereafter, the borax solution and guar polymer were mixed for crosslinking, and the polymer was adjusted to a $\mathrm{pH}$ of 8.5. Third, once set up 8 groups of parallel experiments, the enzyme breakers were added separately to $500-\mathrm{mL}$ the cross-linking solution $(0.1 \mathrm{~g}$ enzyme breaker per liter of solution). The enzyme breakers included mannanase I, mannanase II, amylase, cellulase, pectinase, xylanase, galactosidase, and glucanase [36-38]. Finally, the mixed solution was stirred continuously at a rate of $170 \mathrm{~s}^{-1}$ and at $158^{\circ} \mathrm{F}$ [39]. The viscosity of the fracturing fluids was measured at 20 min intervals using a rotational viscometer to study the effect of different enzyme breakers on the temperature and shear resistance of the fracturing fluid.

Proppant sedimentation experiments were performed with gravel suspended in $0.4 \%$ $w / w$ polymer solution according to a ratio of 3:7 at $158^{\circ} \mathrm{F}$. This experiment evaluates the sand suspending performance of the fracturing fluid with the addition of different enzyme breakers $[40,41]$.

\subsubsection{Gel-Breaking Efficiency of Breakers}

Based on the temperature and shear resistances of the fracturing fluids, as well as the sand-suspending performance after the addition of the different enzyme breaker [39], the relatively suitable mannanase I, mannanase II, and galactosidase breakers were selected for further experiments. First, the gels were prepared as per the procedure outlined in the previous section [42]. Once set up 3 groups of parallel experiments to conduct the assay, mannanase I, mannanase II, and galactosidase were added separately to a 500-mL mixture of fracturing fluid (0.02 g enzyme breaker per liter) $[43,44]$. Finally, the change in the viscosity of the guar polymer was measured using a rotary viscometer to study the gel-breaking efficiencies of the different enzymes. The optimal gel breaker based on the breaking efficiency/performance under simulated the reservoir conditions $\left(158^{\circ} \mathrm{F}, \mathrm{pH}=8.5\right)$ of the Xinjiang Shengli Oilfield was selected. We simultaneously conducted comparative experiments to determine the breaking efficiency of the ammonium persulfate breaker.

\subsubsection{Reservoir Damage by the Breaker after the Fracturing Operation}

Crosslinked guar samples were prepared. The samples were adjusted to a $\mathrm{pH}$ of 8.5 and either ammonium persulfate or mannanase II breakers were added to conduct the gel-breaking experiments at $158^{\circ} \mathrm{F}$ and other wider temperature range. The samples were left overnight at the breaking temperature to facilitate maximum breakage. The next day, to estimate the amount of unbroken polymer and residue generated after breakage, these samples were subjected to a residue-after-break procedure [45]. The contents were centrifuged at $3000 \mathrm{rpm}$ for $30 \mathrm{~min}$ and filtered. To calculate the amount of residue recovered, the gel residue was weighed using weighing paper. Subsequently, the weighting paper and the residue were dried for another $12 \mathrm{~h}$ and reweighed to ensure moisture removal. 
To further examine the molecular size of the guar polymer after it is "completely broken". The changes in the molecular size of the guar polymer before and after the gel-breaking under simulated the reservoir conditions $\left(158^{\circ} \mathrm{F}, \mathrm{pH}=8.5\right)$ was analyzed by the laser particle size analyzer [46].

\subsubsection{Best-Use Concentrations of Mannanase II under Different Environmental Conditions}

In a typical experiment, viscometric assays of guar polymer solutions were performed within a temperature range of $104-158^{\circ} \mathrm{F}$ and $\mathrm{pH}$ values (7-8.5) conditions with the use of a rotational viscometer, thereby further evaluating the gel-breaking performance of mannanase II and optimal dosage under different conditions [36]. The gels were prepared as per the procedure outlined in Section 2.2.1. The temperature was adjusted by means of water-bath heating while the alkalinity was adjusted by adding the $\mathrm{pH}$ regulator. Finally, a rotational viscometer was used to measure the apparent viscosity of the fracturing fluid sample under different temperature and $\mathrm{pH}$ conditions to determine optimal enzyme dosage.

\subsubsection{Statistical Analysis}

Statistical analyses were performed using SPSS v26.0 (IBM, Chicago, IL, USA). Oneway ANOVA was performed followed by Duncan test [47], where $p<0.05$ was considered significant.

\section{Results and Discussion}

\subsection{Effect of Breaker on Shear Resistance Performance and Sand-Suspending Performance of the Fracturing Fluid}

Considering that the breaker and other fracturing additives are simultaneously injected into the well in the fracturing operating process, the fracturing fluid requires a high viscosity to effectively transfer pressure and carry the proppants. Therefore, after adding the enzyme breaker during the fracturing operation, we must consider the effects of the temperature, shear resistance, and suspended sand performance on the fracturing fluids [23].

In this study, eight candidate enzymes were selected, their temperature and shear resistance performance with respect to the guar polymers were investigated by analyzing the change in the viscosity of the solution at a shear rate of $170 \mathrm{~s}^{-1}$ and at $158^{\circ} \mathrm{F}$ for the addition of each breaker. As shown in Figure 1, all curves first decrease with the shear time and then tend to maintain a plateau when the temperature remains at $158^{\circ} \mathrm{F}$. In Figure 1a, $0.1 \mathrm{~g} / \mathrm{L}$ concentrations of xylanase and glucanase were unable to maintain a continuous downward trend for the fracturing fluid viscosity. In contrast, the same concentrations of mannanase I, mannanase II, amylase, cellulase, galactosidase, and alkaline pectinase directly caused the fracturing fluid to liquefy, such that the fracturing fluid was unable to complete the task of generating high-conductivity fractures and transporting the proppant into the fractures. Therefore, to reduce the speed of degradation, lower concentrations of these preferred breakers were considered. However, based on related literature and previous experiment judgment, low-concentration cellulase, amylase and pectinase alone cannot completely reduce the viscosity of guar gum polymer $[1,5,18]$. Comprehensive consideration of cost and degradation speed, lower concentrations of mannanase I, mannanase II, and galactosidase breakers were used. Figure $1 \mathrm{~b}$ shows that lower-concentration enzymes, particularly mannanase II, can still reduce the viscosity of the guar polymers. Moreover, after shearing for $60 \mathrm{~min}$ at $158^{\circ} \mathrm{F}$, the viscosity of the fracturing fluids is greater than $50 \mathrm{mPa} \cdot \mathrm{s}$, satisfying the application requirements for the fracturing fluid [13]. 


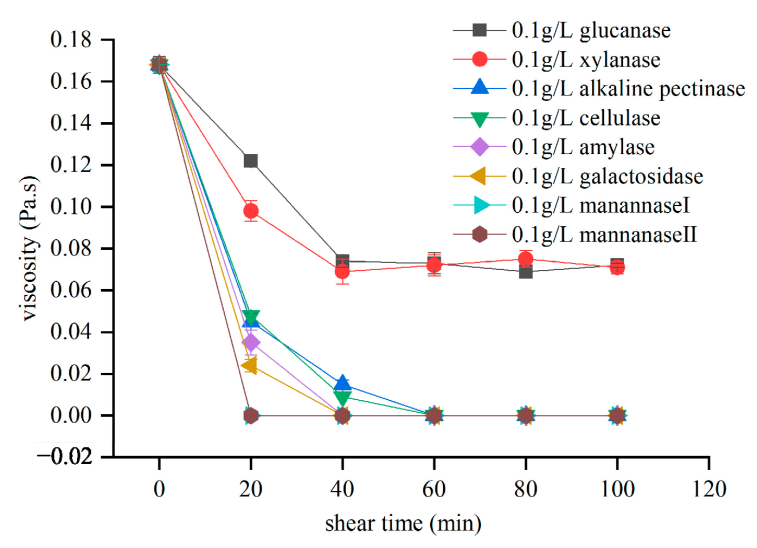

(a)

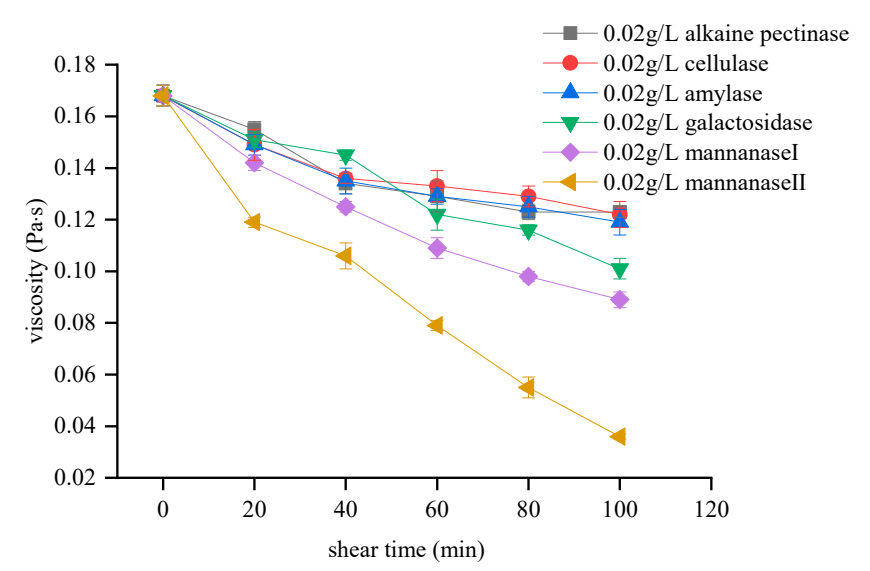

(b)

Figure 1. Temperature tolerance and shearing resistance of the fracturing fluid after the addition of different enzyme breakers at a shear rate of $170 \mathrm{~s}^{-1}$ and at $158^{\circ} \mathrm{F}$. (a) Comparison of the temperature and shearing resistance performance of the fracturing fluid after the addition of the selected enzymes and (b) comparison of the temperature and shearing resistance performance of the fracturing fluid after the addition of the preferred enzymes at low concentrations.

Fracturing fluids should have high viscosity to carry the proppant in the initial phase; otherwise, low viscosities significantly affect the effectiveness of fracturing [11]. The temperature and shear resistance of the fracturing fluid after adding the preferred enzymes was confirmed. Even if the viscosity of the fracturing fluid after the addition of the mannanase I, mannanase II, and galactosidase declines more rapidly, a high viscosity can be maintained at $158^{\circ} \mathrm{F}$. Therefore, based on our judgment, the fluid also has good sand suspending performance. The proppant sedimentation experiments were performed with 550-830 $\mu \mathrm{m}$ gravel suspended in a guar polymer solution at $158{ }^{\circ} \mathrm{F}$ to evaluate the sand suspending performance of the fracturing fluids. Figure 2 lists the state of the suspended sand in the fracturing fluid after adding the preferred enzymes at $158^{\circ} \mathrm{F}$ over time. Based on Figure 2, the sand-suspended fracturing fluid after adding mannanase II was still able to carry sand for more than $120 \mathrm{~min}$, which can be ascribed to the excellent viscoelasticity of the fracturing fluid at $158^{\circ} \mathrm{F}$. In comparison, the previous literature also pointed out that the fracturing fluid added with ammonium persulfate breaker may also lose its sand-carrying capacity within $60 \mathrm{~min}$ due to excessive degradation [40]. Therefore, these enzymes should have major implications for hydraulic fracturing, such as for further gel-breaking performance research. 
(a)

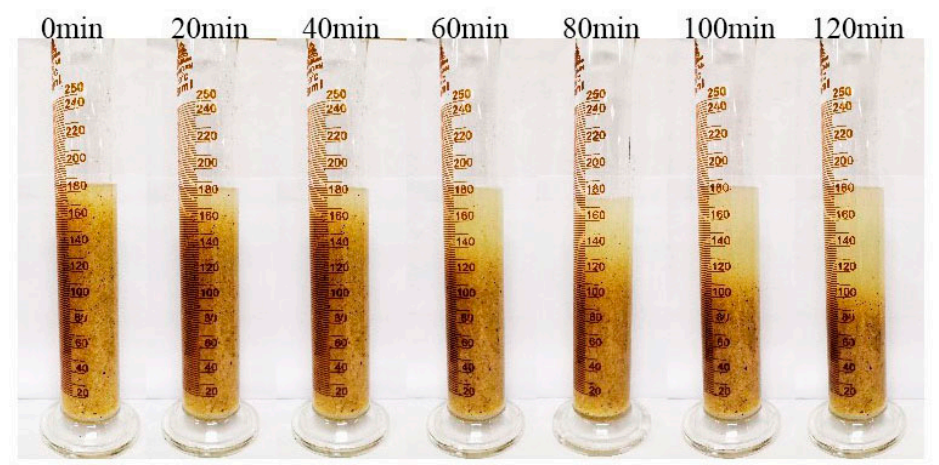

(b)

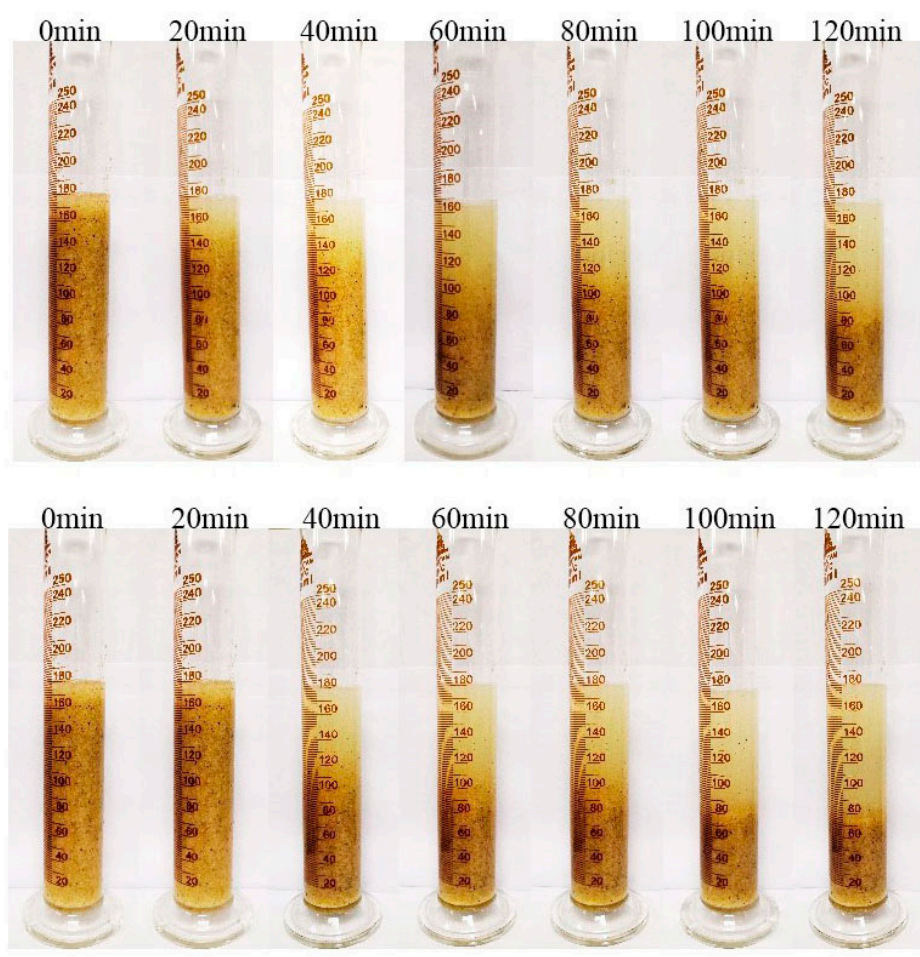

Figure 2. Sand-carrying ability of the fracturing fluid after the addition of the preferred enzymes: (a) galactosidase, (b) mannanase I, and (c) mannanase II.

\subsection{Gel-Breaking Efficiency of Breakers}

When the fracturing fluid completes the task of carrying the proppant to support new fractures, its viscosity must drop rapidly and turn it into a fluid with strong flowability, facilitating its flow-back to the surface [37,38]. Therefore, we must investigate the gel-breaking efficiency of the breaker. Figure 3 shows the results for the rheology study of the fracturing fluid corresponding to different breakers at $158^{\circ} \mathrm{F}$ and a $\mathrm{pH}$ of 8.5 . The effectiveness of the enzyme breakers can be indirectly measured via viscosity experiments. These results indicate that mannanase II offers significant advantages over other single hydrolases. For a given concentration of all the breakers, mannanase II effectively induced the breakage of the crosslinked polymer, whereas the other enzyme breakers were not as effective. Mannanase II is the key enzyme in the hydrolysis of mannan and randomly degrades the $\beta-1,4$-glycosidic linked backbone of mannan $[48,49]$. The mannanase II is produced by a strain of Bacillus amylose isolated from the konjac field, and after purification, the enzyme shows maximum activity at $\mathrm{pH} 7.0$ and $104^{\circ} \mathrm{F}$ with guar gum as substrate and perform high stability at a range of $\mathrm{pH}$ 5-9. In, addition, the alkali stability of mannanase II is better, which is slightly higher than the reported enzyme [31,48]. Russell showed that the surface of the protein has a strong protective effect on the catalytic region of the core, 
and that the alkaline stability of the enzyme is not determined by the electrostatic force of the active center of the enzyme, but by the interaction of multiple factors $[50,51]$. The stronger alkali stability of mannanase II may be that its surface protects the core catalytic region better, and it is a long process to explain the alkaliphilicity of the enzyme.

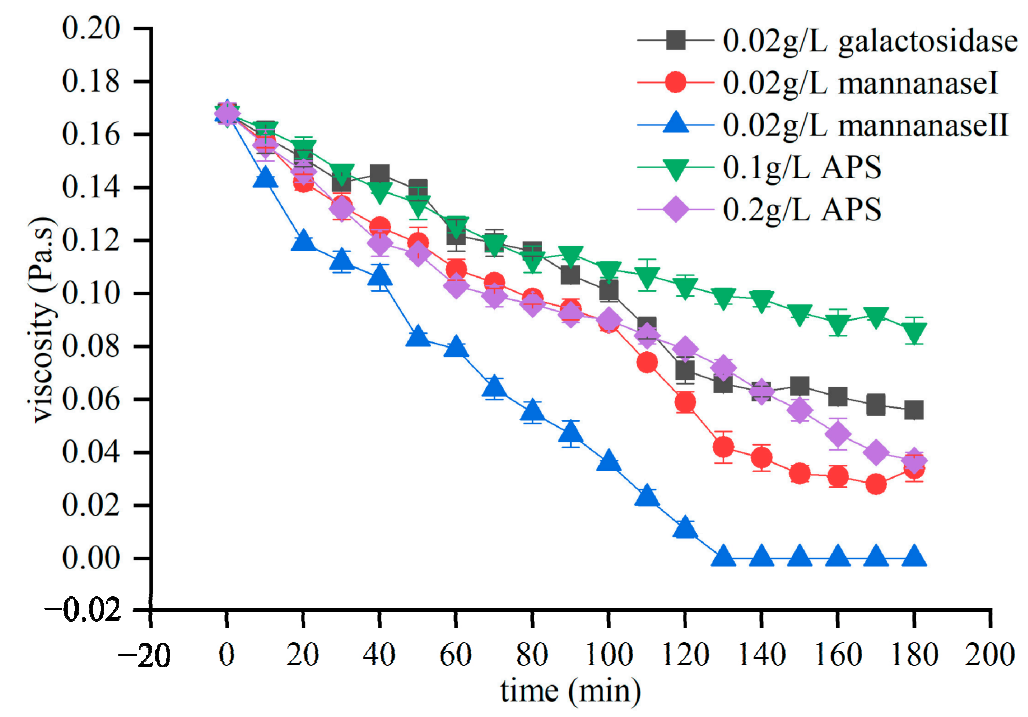

Figure 3. Viscosity changes in the fracturing fluid after adding high-performance breakers under simulated reservoir conditions.

Previous studies have shown that oxidative gel breakers can effectively break gels in high-temperature reservoirs, but when they are below the activation temperature, the efficiency of breaking gel will be greatly reduced $[10,12,13]$. Compared with the ammonium persulfate breaker, an oxidative breaker, mannanase II was highly reactive, such that the overall process afforded a greater reduction in the viscosity. Overall, under simulated Xinjiang Shengli Oilfield reservoir conditions $\left(158^{\circ} \mathrm{F}, \mathrm{pH}=8.5\right)$, mannanase II showed superior performance and in smaller amounts compared with other common breakers.

\subsection{Reservoir Damage by the Breaker after the Fracturing Operation}

The effectiveness of the breaker can not only be characterized by viscosity of fracturing fluid, but also by the residual amount and particle size of polymer. The residual amount of polymer includes unbroken polymer and residues generated after the gel is broken. The presence of residue can cause flow reduction via the plugging of the formed fracture. Thus, a decrease in the amount of the residue corresponds to both decreased formation damage and increased production. In summary, the amount of residue is an important factor to consider in hydraulic fracturing. To evaluate the amount of residue generated by the breakers, residue-after-break experiments were conducted at $158{ }^{\circ} \mathrm{F}$ and other wider temperature range (Figure 4). The amount of residue generated by adding smaller concentrations of mannanase II was also $<600 \mathrm{mg} / \mathrm{L}$, which conforms to the criterion for evaluating the performance of water-based fracturing fluids [28,47]. Moreover, we observed that upon adding higher oxidizer concentrations $(0.1 \mathrm{~g} / \mathrm{L})$ at the higher temperature of $158^{\circ} \mathrm{F}$, the mannanase II breaker still produced less residue than ammonium persulfate (Figure 4). 


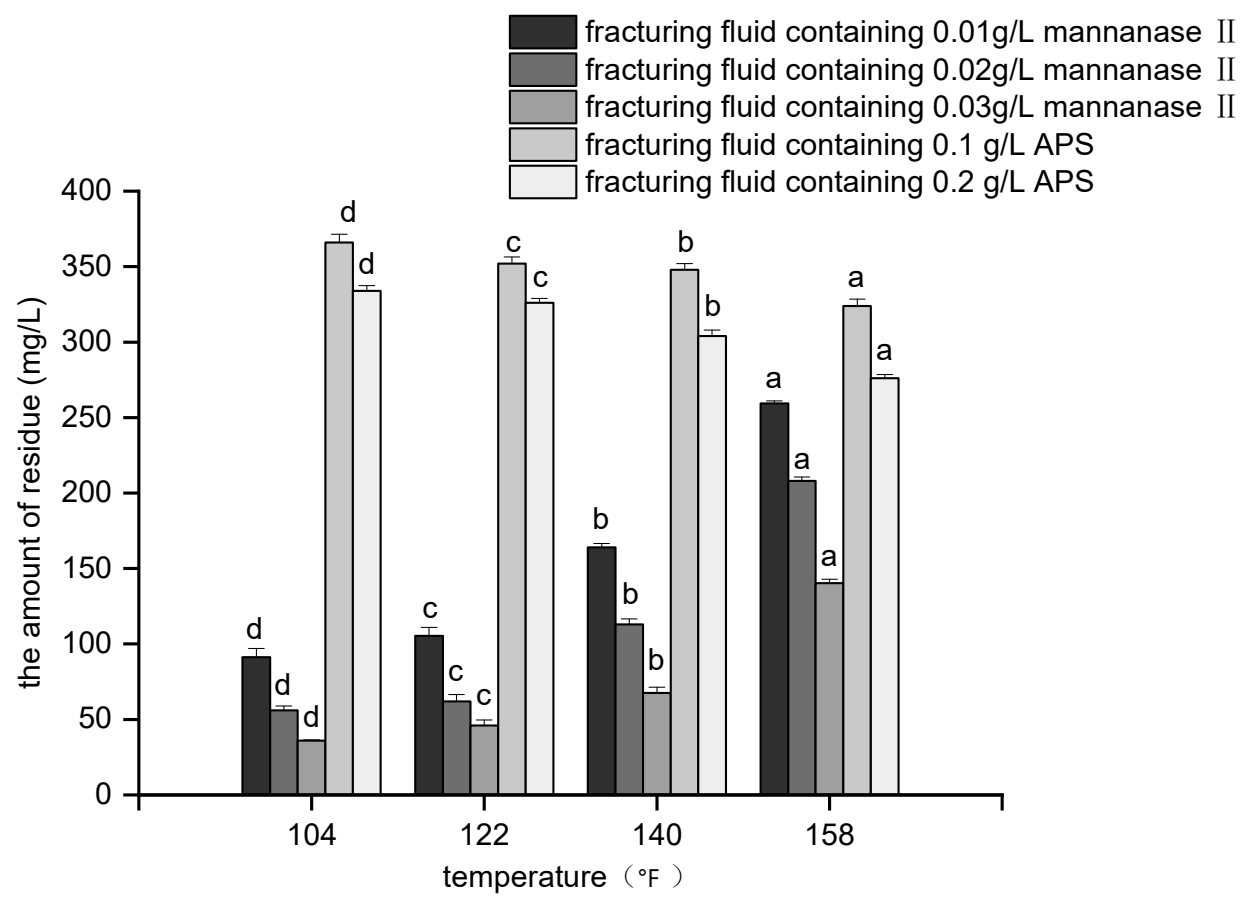

Figure 4. Residue-after-break results following the addition of different breakers under different temperature conditions (for each group of bars, the means indicated using different letters are significantly different at $p<0.05$, where the vertical bars represent $\pm \operatorname{SD}(n=3))$.

Figure 4 also demonstrates that, for a given amount of enzyme breaker, a higher temperature resulted in the generation of a greater amount of residue. In contrast, for a given amount of ammonium persulfate, a higher temperature resulted in the generation of a smaller amount of residue. This difference can be attributed to the different effects of temperature on the breakers $[13,24,28]$.

Compared with the oxidative breaker, the mannanase II induces more exhaustive and homogeneous breakage under the reservoir conditions [11,19]. To further verify this result, the experiment for the change in the molecular size of the guar during the gelbreaking process was carried out via a laser particle size analyzer at alkaline $(\mathrm{pH}=8.5)$ and medium temperature $\left(158^{\circ} \mathrm{F}\right)$ conditions. Based on Figure 5, the molecular diameter of the fracturing fluid without the breaker is concentrated around $197.99 \mu \mathrm{m}$, while the molecular diameter after gel breaking with the mannanase II breaker is $42.7922 \mu \mathrm{m}$. The molecular diameter after gel breaking with a higher concentration of ammonium persulfate in the control group was $71.3062 \mu \mathrm{m}$. The experiment results showed that, compared with the use of ammonium persulfate breaker, there is a significant reduction in the size of the fracturing fluid after adding the enzyme breaker. Guar polymer molecules with this size can easily flow through the porous medium and improve reservoir conductivity [24].

Therefore, these results further confirm that mannanase II yields a better degradation performance than oxidative breakers. In addition, with its environmental benefits and cleaning ability, it can enhance both governmental and public trust in the hydraulic fracturing process. 


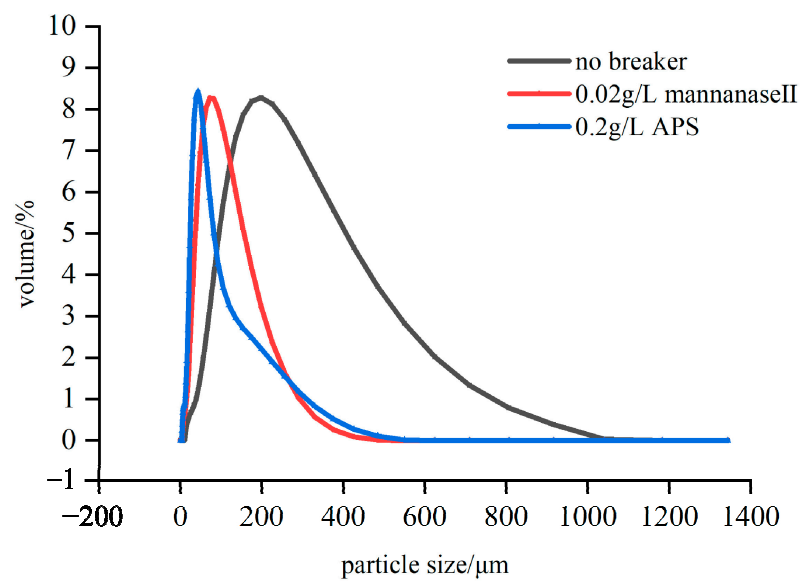

Figure 5. The change in the molecular size of the guar polymer during the gel-breaking process.

\subsection{Best-Use Concentrations of Mannanase II under Different Environmental Conditions}

The mannanase II breaker exhibited a dose-response effect. When the concentration of the enzyme breaker was too high, the fracturing fluid lost its shear resistance; however, when it was low, gel breaking was not complete [38,43]. The use of an appropriate amount of enzyme can ensure both environmental and economic benefits. Previous residue experiments have proven that enzyme breaker activity is affected by temperature. To establish guidelines for optimal mannanase II concentrations under different environmental conditions, histograms corresponding to the minimum enzyme amount required for gel breakage under different $\mathrm{pH}$ and temperature conditions were plotted (Figure 6). The results obtained demonstrate that any reduction in the gel viscosity depends on the breaker concentration, as well as on the temperature and $\mathrm{pH}$ of the fracturing fluid [6,22]. Thus, different concentrations of mannanase II at different temperatures and $\mathrm{pH}$ values showed different breakage results. Mannanase II exhibits highly efficient gel-breaking performance over a wide range of temperatures $\left(104-158^{\circ} \mathrm{F}\right)$ in both alkaline and neutral environments. Moreover, a temperature of $140^{\circ} \mathrm{F}$ was identified as the critical point for the change in the activity of this breaker. The amount of enzyme required to break the gel increase significantly with an increase in the temperature. In addition, the enzymes showed higher activity in neutral environments $[45,46]$; therefore, the amount of mannanase II breaker required to break the gel in neutral environments was less than that required in alkaline environments.

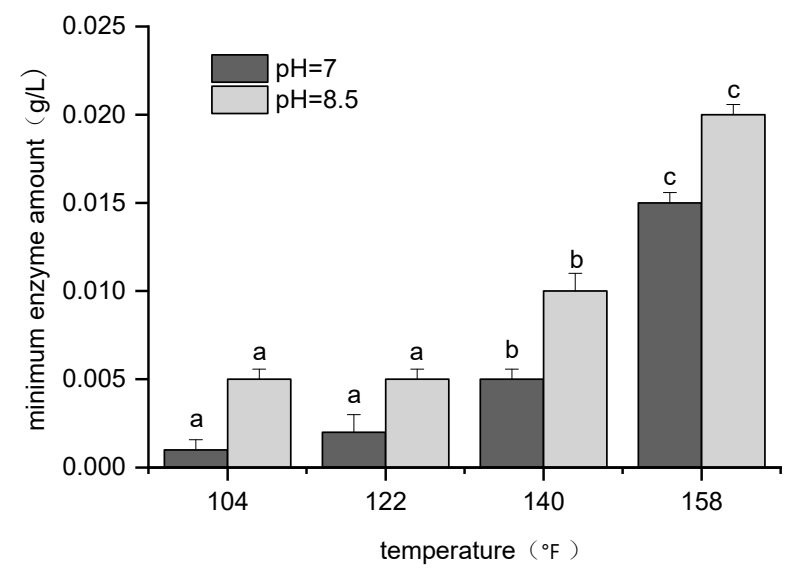

Figure 6. Plot of the minimum enzyme amount required to break the gel under different temperature and $\mathrm{pH}$ conditions (for each group of bars, the different letters indicate the means that are significantly different at $p<0.05$, where the vertical bars represent $\pm \operatorname{SD}(n=3))$. 


\section{Conclusions}

In this study, we analyzed the feasibility of using the mannanase II enzyme in breaking borate-crosslinked guar gum gel under simulated the reservoir conditions $\left(158^{\circ} \mathrm{F}, \mathrm{pH}=8.5\right)$ of the Xinjiang Shengli Oilfield. The results obtained showed that, compared with other gel breakers, mannanase II exhibits superior gel-breaking performance. The residue measurement experiments showed that mannanase II provides a cleaner and more homogeneous polymer breakage than other breakers. Using a small quantity of mannanase II, it was possible to realize rapid gel-breaking while a much larger concentration of other enzymes was required to achieve similar results. The residue measurement experiments showed that mannanase II provides a cleaner and more homogeneous polymer breakage than other breakers. Experiments on the factors influencing the breaking performance also indirectly showed that mannanase II retains its activity over a wide range of application temperatures $\left(104-158^{\circ} \mathrm{F}\right)$ and $\mathrm{pH}$ values (7-8.5) in hydraulic fracturing. Overall, mannanase II was found to be a highly efficient, economical, and environmentally friendly breaker. Therefore, during oil production in low-permeability oil fields with medium temperatures and alkaline conditions, the advantages of mannanase II are unmatched by other gel breakers. Mannanase II is characterized by a better gel-breaking effect under low and medium temperature and neutral conditions. In future studies, we will conduct field experiments in low-permeability oil reservoirs to further demonstrate the excellent performance of this enzyme breaker. In addition, we speculate that this breaker has significant potential for applications in low-permeability oilfield development.

Author Contributions: P.L., Y.F., G.S., and J.L. giving the idea for this project, helping in the case of scientific problems. Y.M. was responsible for planning and performing experiments as well as writing the main part of the manuscript. F.Z. and X.J. were responsible for helping with experiments operation and data collation. B.J., P.L., and Y.M. were responsible for the final correction and English proofing. All authors have read and agreed to the published version of the manuscript.

Funding: This work was supported by the Foundation (No. ZZ20190411) of State Key Laboratory of Biobased Material and Green Papermaking, Qilu University of Technology, Shandong Academy of Sciences.

Institutional Review Board Statement: Not applicable.

Informed Consent Statement: Not applicable.

Data Availability Statement: Data is contained within the article.

Acknowledgments: The authors thank the management of the State Key Laboratory of Bio-based material \& Green Papermaking for support of this study and permission to publish this paper.

Conflicts of Interest: The authors declare no conflict of interest.

Sample Availability: Samples of the compounds are available from the authors.

\section{References}

1. Stringfellow, W.T.; Domen, J.K.; Camarillo, M.K.; Sandelin, W.L.; Borglin, S. Physical, chemical, and biological characteristics of compounds used in hydraulic fracturing. J. Hazard. Mater. 2014, 275, 37-54. [CrossRef]

2. Barati, R.; Liang, J.T. A Review of Fracturing Fluid Systems Used for Hydraulic Fracturing of Oil and Gas Wells. J. Appl. Polym. Sci. 2014, 131, 40735. [CrossRef]

3. Jennings, A.R., Jr. Fracturing Fluids-Then and Now. J. Pet. Technol. 1996, 48, 604-610. [CrossRef]

4. Bose, C.; Swartz, L.; Gupta, A.; Barati, R. Dual Application of Polyelectrolyte Complex Nanoparticles as Enzyme Breaker Carriers and Fluid Loss Additives for Fracturing Fluids. In Proceedings of the SPE/CSUR Unconventional Resources Conference, Calgary, AB, Canada, 30 September 2014; p. 171571.

5. Al-Muntasheri, G.; Li, L.; Liang, F.; Gomaa, A. Concepts in Cleanup of Fracturing Fluids Used in Conventional Reservoirs: A Literature Review. SPE Prod. Oper. 2018, 33, 196-213. [CrossRef]

6. Robinson, G.; Ross-Murphy, S.; Morris, E. Viscosity-Molecular Weight Relationships, Intrinsic Chain Flexibility, and Dynamic Solution Properties of Guar Galactomannan. Carbohydr. Res. 1982, 107, 17-32. [CrossRef] 
7. Trabelsi, S.; Kakadjian, S. Comparative Study Between Guar and Carboxymethylcellulose Used as Gelling Systems in Hydraulic Fracturing Application. In Proceedings of the SPE Production and Operations Symposium, Oklahoma City, OK, USA, 23-26 March 2013; p. 164486.

8. Wilson, A. An Innovative Approach to Gel Breakers for Hydraulic Fracturing. J. Pet. Technol. 2017, 69, 48-51. [CrossRef]

9. Al-Hulail, I.; Al-Khabbaz, H.; Al-Janabi, Y.; Rahal, R.; Dahlan, M.; Al-Marshad, K. Fracturing Fluid Encapsulated Breaker: High Temperature up to $330^{\circ} \mathrm{F}$. In Proceedings of the SPE EOR Conference at Oil and Gas West Asia, Muscat, Oman, 28 March 2018; p. 190379.

10. Prajakta, P.; Ramesh, M.; Nisha, P. Novel Controlled-Release Breakers for High-Temperature Fracturing. In Proceedings of the North Africa Technical Conference and Exhibition, Cairo, Egypt, 15-17 April 2013; p. 164656.

11. Soe, A.; Azahar, B.; Tunio, S. Fracturing Fluid (Guar Polymer Gel) Degradation Study by using Oxidative and Enzyme Breaker. Res. J. Appl. Sci. Eng. Technol. 2012, 4, 1667-1671.

12. Watson, W.; Aften, C.; Previs, D.; Chemicals, K. Delayed-Release Coatings for Oxidative Breakers. In Proceedings of the SPE International Symposium and Exhibition on Formation Damage Control, Lafayette, LA, USA, 10-12 September 2010; p. 127895.

13. Sarwar, M.; Cawiezel, K.; Nasr-El-Din, H. Gel Degradation Studies of Oxidative and Enzyme Breakers to Optimize Breaker Type and Concentration for Effective Break Profiles at Low and Medium Temperature Ranges. In Proceedings of the SPE Hydraulic Fracturing Technology Conference, The Woodlands, TX, USA, 24-26 January 2011; p. 140520.

14. Caulfield, M.; Qiao, G.; Solomon, D. Some Aspects of the Properties and Degradation of Polyacrylamides. Chem. Rev. 2010, 33, 274. [CrossRef]

15. Funkhouser, G.; Norman, L. Synthetic Polymer Fracturing Fluid for High-Temperature Applications. In Proceedings of the International Symposium on Oilfield Chemistry, Houston, TX, USA, 5 February 2003; p. 80236.

16. Ayoub, J.; Hutchins, R.; Van der Bas, F.; Cobianco, S.; Emiliani, C.; Glover, M.; Marino, S.; Nitters, G.; Norman, D.; Turk, G. New Results Improve Fracture-Cleanup Characterization and Damage Mitigation. SPE Prod. Oper. 2009, 24, 374-380. [CrossRef]

17. Sumner, A.J.; Plata, D.L. Oxidative Breakers Can Stimulate Halogenation and Competitive Oxidation in Guar-Gelled Hydraulic Fracturing Fluids. Environ. Sci. Technol. 2019, 53, 8216-8226. [CrossRef]

18. Brannon, H.; Tjon-Joe-Pin, R.; Carman, P.; Wood, W. Enzyme Breaker Technologies: A Decade of Improved Well Stimulation. In Proceedings of the SPE Annual Technical Conference and Exhibition, Denver, CO, USA, 5 October 2003; p. 84213.

19. Vengosh, A.; Jackson, R.B.; Warner, N.; Darrah, T.H.; Kondash, A. A Critical Review of the Risks to Water Resources from Unconventional Shale Gas Development and Hydraulic Fracturing in the United States. Environ. Sci. Technol. 2014, 48, 8334-8348. [CrossRef] [PubMed]

20. Fogang, L.; Kamal, M.; Sultan, A. Viscosity-Reducing Agents (Breakers) for Viscoelastic Surfactant Gels for Well Stimulation. Energy Fuels 2020, 34, 15686-15700. [CrossRef]

21. Wang, Z.; Bai, B.; Zhou, E.; Pu, J.; Schuman, T. Experimental Evaluation of Oxidizing Breakers for a Polyacrylamide-Based Re-Crosslinkable Preformed Particle Gel. Energy Fuels 2019, 33, 5001-5010. [CrossRef]

22. Peterson, M.; Daniel, R.; Danson, M.; Eisenthal, R. The dependence of enzyme activity on temperature: Determination and validation of parameters. Biochem. J. 2007, 403, 615. [CrossRef]

23. Xin, M.; Ping, S.; Licheng, L.; Qian, D.; Guang, L.; Yao, C. Low-temperature pH-regulable gel-breaking of galactomannan-based fracturing fluids by the mannanase from Bacillus aerius. Int. Biodeterior. Biodegrad. 2011, 160, 105226.

24. Barati, R.; Johnson, S.J.; McCool, S.; Green, D.W.; Willhite, G.P.; Liang, J.-T. Fracturing fluid cleanup by controlled release of enzymes from polyelectrolyte complex nanoparticles. J. Appl. Polym. Sci. 2011, 121, 1292-1298. [CrossRef]

25. Bhatia, S.; Singh, A.; Batra, N.; Singh, J. Microbial production and biotechnological applications of alpha-galactosidase. Int. J. Biol. Macromol. 2020, 150, 1294-1313. [CrossRef] [PubMed]

26. Li, C.; Kumar, A.; Luo, X.; Shi, H.; Liu, Z.; Wu, G. Highly alkali-stable and cellulase-free xylanases from Fusarium sp. 21 and their application in clarification of orange juice. Int. J. Biol. Macromol. 2020, 155, 572-580. [CrossRef]

27. Nahar, N.; Ripplinger, D.; Pryor, S.W. Process yield and economic trade-offs for enzymatic hydrolysis of alkaline pretreated corn stover. Biomass Bioenergy 2017, 99, 97-105. [CrossRef]

28. Zhang, B.; Huston, A.; Whipple, L.; Urbina, H.; Barrett, K.E.; Wall, M.; Hutchins, R.D.; Mirakyan, A. A Superior, High-Performance Enzyme for Breaking Borate Crosslinked Fracturing Fluids Under Extreme Well Conditions. SPE Prod. Oper. 2013, 28, 210-216. [CrossRef]

29. Angural, S.; Rana, M.; Sharma, A.; Warmoota, R.; Puri, N.; Gupta, N. Combinatorial Biobleaching of Mixedwood Pulp with Lignolytic and Hemicellulolytic Enzymes for Paper Making. Indian. J. Microbiol. 2020, 60, 383-387. [CrossRef] [PubMed]

30. Ouyang, D.; Deng, J.; Zhou, K.; Liang, Y.; Chen, Y.; Wang, D.; Zhong, J.; Sun, Y.; Li, M. The effect of deacetylation degree of konjac glucomannan on microbial metabolites and gut microbiota in vitro fermentation. J. Funct. Foods. 2020, 66, 103796. [CrossRef]

31. Yin, L.; Tai, H.; Jiang, S. Characterization of Mannanase from a Novel Mannanase-Producing Bacterium. J. Agric. Food. Chem. 2012, 60, 6425-6431. [CrossRef] [PubMed]

32. Battistel, E.; Bianchi, D.; Fornaroli, M.; Cobianco, S. Enzymes breakers for viscosity enhancing polymers. J. Pet. Sci. Eng. 2011, 77, 10-17. [CrossRef]

33. Tao, L.; Li, Z.; Bi, Y.; Zhang, J. Multi-combination exploiting technique of ultra-heavy oil reservoirs with deep and thin layers in Shengli Oilfield. Pet. Explor. Dev. 2010, 37, 732-736. [CrossRef] 
34. Yang, W.; Sc, A.; Kz, C.; You, H.; Hai, Y. Pressure-transient analysis of water injectors considering the multiple closures of waterflood-induced fractures in tight reservoirs: Case studies in Changqing Oilfield, China. J. Pet. Sci. Eng. 2019, 172, 643-653.

35. Cao, P.F.; Mangadlao, J.D.; Advincula, R.C. Stimuli-Responsive Polymers and their Potential Applications in Oil-Gas Industry. Polym. Rev. 2015, 55, 706-733. [CrossRef]

36. Li, H.; Liu, S.; Zhu, Z.; Hao, L.; Deyi, Z.; Chuwen, G. Experimental Investigation on Rock Breaking Performance of Cutter Assisted with Hydraulic Fracturing. Eng. Fract. Mech. 2021, 248, 107710. [CrossRef]

37. Jie, W.; Yha, B.; Yan, Z.; Fza, B.; Eya, B.; Ru, W. Study of Fracturing Fluid on Gel Breaking Performance and Damage to fracture conductivity-ScienceDirect. J. Pet. Sci. Eng. 2020, 193, 107443.

38. Lin, X.; Zhang, S.; Zheng, C.; Yang, P. Optimal production of enzymatic guar gel breaker by Bacillus sp. M1-4 and its potential in hydraulic fracturing. Int. J. Oil Gas Coal Technol. 2016, 12, 231-247.

39. Bankole, K.S.; Matthew, B. Applications of Oilfield Produced Formation Water for Fracturing Fluid. Res. J. Appl. Sci. Eng. Technol. 2014, 7, 2208-2216. [CrossRef]

40. Priscille, E.; Siddhamshetty, P.; Cao, K.; Mukherjee, R.; Kwon, J. Incorporation of sustainability in process control of hydraulic fracturing in unconventional reservoirs. Chem. Eng. Res. Des. 2018, 139, 62-76.

41. Murthy, R.; Chavali, M. A novel hydraulic fracturing gel realization for unconventional reservoirs. Beni-Suef Univ. J. Basic Appl. Sci. 2020, 9, 1-7. [CrossRef]

42. Xiong, B.; Miller, Z.; Roman-White, S.; Tasker, T.; Farina, B.; Piechowicz, B.; Burgos, W.D.; Joshi, P.; Zhu, L.; Gorski, C.A.; et al Chemical Degradation of Polyacrylamide during Hydraulic Fracturing. Environ. Sci. Technol. 2017, 52, 327-336. [CrossRef] [PubMed]

43. Aliu, A.; Guo, J.; Wang, S.; Zhao, X. Hydraulic fracture fluid for gas reservoirs in petroleum engineering applications using sodium carboxy methyl cellulose as gelling agent. J. Nat. Gas Sci. Eng. 2016, 32, 491-500. [CrossRef]

44. Lin, X.; Zhang, S.; Wang, Q.; Feng, Y.; Shuai, Y. Improving the fracturing fluid loss control for multistage fracturing by the precise gel breaking time design. J. Nat. Gas Sci. Eng. 2015, 25, 367-370. [CrossRef]

45. Khanna, A.; Luong, H.; Kotousov, A.; Nguyen, G.D.; Rose, L.F. Residual opening of hydraulic fractures created using the channel fracturing technique. Int. J. Rock Mech. Min. Sci. 2017, 100, 124-137. [CrossRef]

46. Ma, X.; Lei, G.; Wang, Z.; Da, Q.; Zhang, X.; Song, P.; Yao, C. Remediation mechanism of guar degrading bacteria on hydraulic fracturing fluid damage. J. China Univ. Pet. 2018, 42, 100-110.

47. Lawrence, R.A. A pocket calculator program for Duncan's New Multiple Range test and analysis of variance. Comput. Biol. Med. 1984, 14, 357-362. [CrossRef]

48. Liu, J.; Basit, A.; Miao, T.; Zheng, F.; Yu, H.; Wang, Y.; Jiang, W.; Cao, Y. Secretory expression of $\beta$-mannanase in Saccharomyces cerevisiae and its high efficiency for hydrolysis of mannans to mannooligosaccharides. Appl. Microbiol. Biotechnol. 2018, 102, 10027-10041. [CrossRef]

49. Xie, J.; Pan, L.; He, Z.; Liu, W.; Zheng, D.; Zhang, Z.; Wang, B. A novel thermophilic $\beta$-mannanase with broad-range pH stability from Lichtheimia ramosa and its synergistic effect with $\alpha$-galactosidase on hydrolyzing palm kernel meal. Process. Biochem. 2020 88, 51-59. [CrossRef]

50. Russell, A.; Fersht, A. Rational modification of enzyme catalysis by engineering surface charge. Nature 1987, 328, 496-500. [CrossRef] [PubMed]

51. Ma, Y.; Xue, Y.; Dou, Y.; Xu, Z.; Tao, W.; Zhou, P. Characterization and gene cloning of a novel?-Mannanase from alkaliphilic Bacillus sp. N16-5. Extremophiles 2004, 8, 447-454. [CrossRef] [PubMed] 